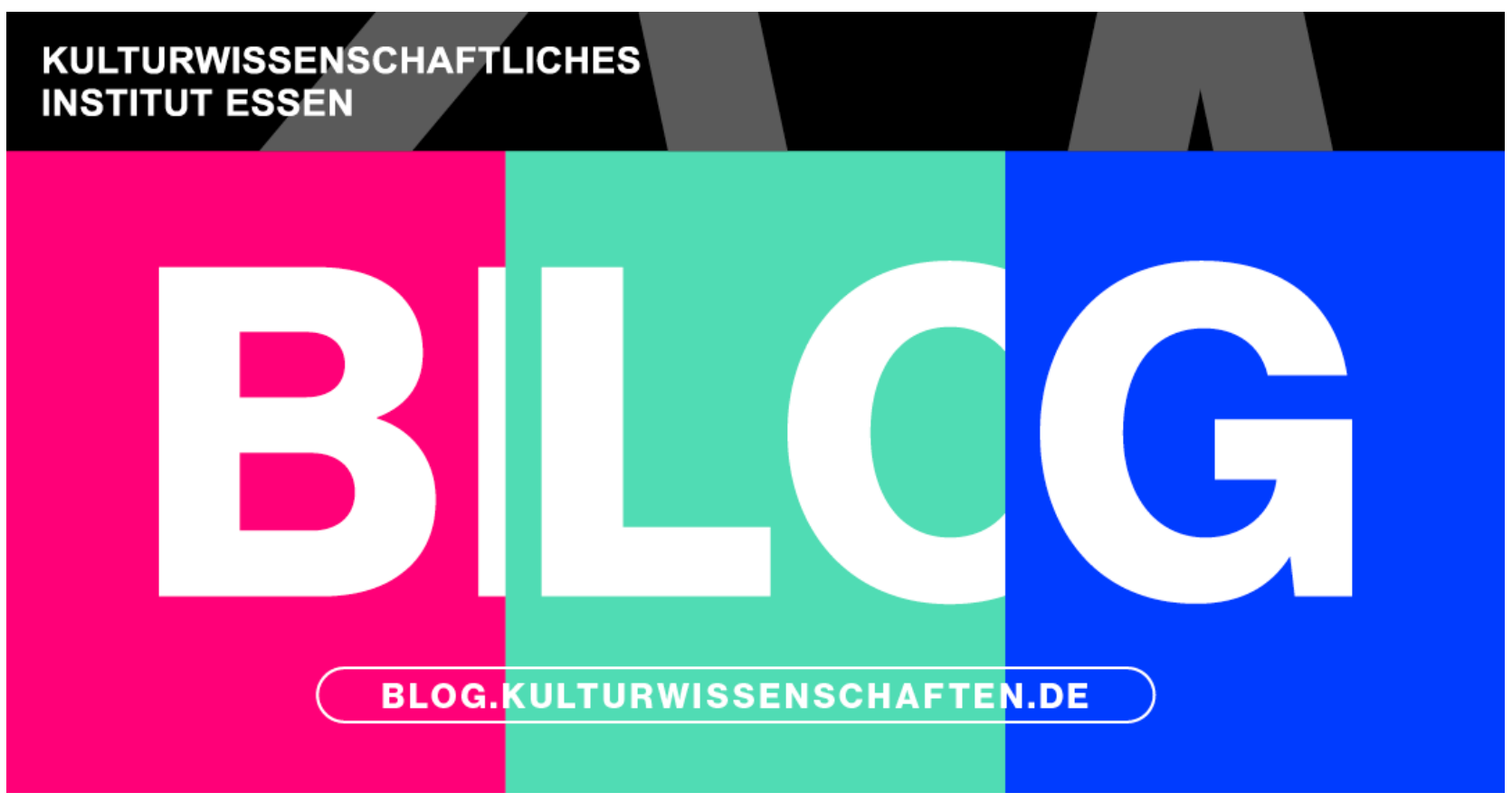

\title{
At the sports ground, with footnotes (I) Stretching for the Fatherland
}

Erschienen in: WORTATLAS

Von: Danilo Scholz

They can be oval, U-shaped, rectangular or in diamond formation. Some adjoin the surrounding landscape, others blend into a larger complex of edifices, and many are girded by bleachers. They come covered by dizzying roof structures or are starkly exposed to the open skies and the elements. They feature pitches of natural grass or artificial turf, often surrounded by cinder or tartan tracks. On at least one side of the Atlantic, they regularly draw crowds the size of which professorial performers in the lecture hall could only dream of. As an outpost of the university, and perhaps more than any other academic locale, the sports ground has been subject to wildly divergent fortunes depending on its national setting.

In today's Germany, the playing field has been largely relegated to the side-lines of higher education; its early history, however, encapsulates the tensions pervading a nation-state struggling to be born. As Napoleon marched eastward in the early nineteenth century, the dozens of principalities, kingdoms, and free cities covering German lands were no match for the French emperor and his troops. The occupation made the lack of a unifying political force painfully obvious to contemporaries. Among them was Friedrich Ludwig Jahn, an educator who, reeling from the humiliation of defeat, conjoined the cause of national liberation and the need for a "body culture" that would steel the German youth for their inevitable military showdown with the French invaders. 
To this end, Jahn devised a system of exercises, many of them adapted from Johann Christoph Friedrich GutsMuths, author of Gymnastics for Youth: Or a practical guide to Delightful and Amusing exercises for the Use of Schools, An Essay Toward the Necessary Improvement of Education Chiefly as It Relates to Body (1793). In order to elevate gymnastics as a form of national self-expression, Jahn coined the term Turnen, a faux-archaism apparently evocative of the chivalric Turnier and designed to underscore the German roots of a practice untarnished by foreign influences. In fact, Jahn feared that French practices of exercise, and dancing in particular, had wreaked havoc in Germany, undermining Teutonic virility and causing an epidemic of effeminacy. Gymnastics, in its German guise, was seen as a means not only to cure this social ill but to forge a new and battle-ready masculinity. In 1811, the first Turnplatz opened in the Hasenheide in Berlin. Precipitated by the Napoleonic Wars, open-air gymnasia popped up in quick succession across German lands.

Jahn's initiative had evidently struck a chord with German youth, who, sensing an exhilarating sense of political and bodily freedom, converted en masse to the Turnvater's ideas. ${ }^{1}$ Many young men enlisted as volunteers in the armed forces or joined makeshift battalions to fight Napoleon, most prominently in the Lützow Free Corps that included the poet Joseph von Eichendorff. Upon their return from the military campaign, veterans of the Free Corps founded student duelling fraternities known as Burschenschaften, the first of which was established at the University of Jena. Immediately after Waterloo, Burschenschaftsturnen rode a wave of nationalist fervour and swept across German universities. Fraternities were formed at the universities of Breslau, Erlangen, Tübingen, Marburg, and Gießen in 1816, in Heidelberg, Königsberg, Kiel, and Rostock in 1817, and in Greifswald, Berlin, Freiburg, Leipzig, Würzburg, Prague and Vienna in 1818. Two years later, this wave crested at the Wartburg festival, organised by two of Jahn's students. In what can only be described as a networking event avant la lettre, up to 500 young people came together to celebrate the victory of the fatherland. After the end of the official festivities, some participants joined in a book burning, with copies of Napoleon's Code Civil amongst the works set aflame.

The authorities harboured doubts about the Turner movement from the beginning, and fears arose that the revolutionary mobilisation would not stop with Bonaparte's exile to Elba. If the students' aim was a unified Germany, it was only a matter of time before the dukes and princes and kings and the patchwork of polities over which they reigned felt the consequences. What ultimately served as pretext for persecution of the movement was the assassination, in March 1818, of the poet August von Kotzebue by the radical student and Turner Karl Ludwig Sand. At the behest of the Austrian chancellor Metternich, the iron hand of the state(s) came down on the unruly young gymnasts. As a result of the so-called Carlsbad Decrees, the open-air gymnasia were shut down, Jahn was barred from entering university towns, and the term Turnen was proscribed. Sand, a member of the Jena Urburschenschaft, was arrested and beheaded in public.

The momentum may have stalled but the Turnsperre (gymnastics ban) did not spell the end of physical exercise in German higher education. University administrators and local teachers tentatively reopened facilities under the more innocuous moniker of 
gymnastische Übungen, even though the ban was not officially lifted until 1842. Still, while Turnen became institutionalised as an academic pastime and practitioners set up a national organisation to represent their interests in 1860, it never regained its initial vigour. For one, Turnen failed to seduce German élites and never penetrated high society. No matter how many invitations the Prussian king received year in, year out, the monarch snubbed the annual pageant of the National Gymnastics Federation. At the same time, the appeal of Turnen also waned amongst the youth. The more instructors narrowed the bounds of permissible exercises, the more students turned elsewhere for inspiration. All eyes were on England: the aristocracy took up the genteel pursuits of cricket and tennis, and the university population increasingly caught wind of the team sports and games played on the British Isles. ${ }^{2}$ At the University of Tübingen, students set up a cricket and lawn tennis club in 1883. To the dismay of the Turn instructors, new playing fields designated for "English games and sports" appeared near the Neckar. ${ }^{3}$

The German Turner movement showcased a remarkable capacity for shooting itself in the foot. When faced with a choice, it opted for self-marginalisation over international fame. Indeed, many members of the German middle classes chafed at the very idea of internationalism. The Olympic Games held in Athens in 1896 could have been a golden opportunity to spread the gospel of Turnen. Instead, officials rejected competition as unGerman - some even called for a boycott - and publicly denigrated the eleven Turner that participated in the Games without their blessing as sell-outs. When the Gymnastics Federation finally sent an official team to the 1908 London Olympics, the results were underwhelming - four years later, the gymnasts promptly declined to participate in the Stockholm Games. ${ }^{4}$

And then there was the latest athletic arrival from the British Isles: football. The game was not exactly welcomed with open arms. The overwhelmingly middle-class Turner movement was appalled by what one teacher baptised "football loutishness" (Fußlümmelei), soon perceived to be a contagion menacing the very integrity of the German Volk. ${ }^{5}$ Some pamphleteers even linked football to infant spine inflammation, nicknamed the "English disease." By contrast, the exclusive boarding schools of Switzerland, steeped in Anglophilia and lousy with the offspring of British industrialists, were more receptive to the ball game. Unlike Turnvereine, the football clubs rarely discriminated on the basis of citizenship and allowed for transnational sociability, at least for the upper echelons of society. ${ }^{6}$ As late as 1914 , however, the membership of Turner associations still dwarfed that of football clubs.

The demise of the Kaiserreich and the birth of the Weimar Republic created new openings for athleticism in academia, but this fresh departure was marred by resentment at what was widely perceived as the unjust treatment meted out to a vanquished Germany. By stipulating that post-war Germany's armed forces be limited to 100.000 men, the Treaty of Versailles, rather than dialling down jingoist effervescence, inadvertently channelled nationalist energies into sporting activities. Revanchist hotheads thrived in the interwar universities and found an outlet in physical exercise, with students at a congress held in Göttingen in 1920 demanding that participation in Leibesübungen be made obligatory. The authorities eventually heeded their appeals. By 1925, students of 
philology at Prussian universities - primarily in training to become secondary-school teachers - were required to complete physical education classes. These changes flabbergasted not a few senior faculty members, who refused to grant Leibesübungen the same academic accreditation hitherto reserved for intellectual pursuits. Such naysayers met in turn with stern disapproval from their colleagues at the medical schools, who, influenced by debates over social hygiene, emphasised the public-health benefits of exercise.

Football's breakthrough occurred in these fraught circumstances. English games, it transpired, could benefit Germans after all. Despite the official demilitarisation of the Weimar Republic, the arms race took a biopolitical turn and was displaced onto the playing fields. More than a century after Jahn's Turnbewegung, athleticism was once again praised as a martial virtue. As university sports were increasingly imbued with the spirit of paramilitary training, the football pitch became a battle zone. "The advantage of football games, especially rugby, compared to other sports, lies in its close affinity to manto-man combat," wrote PE teacher Paul Sturm in 1924. ${ }^{7}$

The National Socialists built on this policy, requiring that all university students complete mandatory PE classes as early as May 1933. It was drummed into even the youngest pupils that agility, fitness, and endurance were indispensable if Germans were to prevail in the struggle for existence (Daseinskampf). Hans-Ulrich Wehler, later one of the most renowned historians of the Federal Republic, would reminisce fondly about his adventures in the youth organisation Deutsches Jungvolk. In the Third Reich, a seemingly endless succession of cross-country races and track meets beckoned. A gifted sportsman, young Wehler proved his mettle and quickly rose through the ranks, ending the war as a deputy Fähnleinführer. For others, there was nothing playful about the athletic obsession of the Nazis. Literary scholar Victor Klemperer - older, more detached and more endangered than Wehler - characterised the pagan divinisation of sports that seeped into academic life as part of the brutalisation of society under Hitler. The whole point, Klemperer argued in The Language of the Third Reich, was to collapse playful competition into military training: the participants are not sports afficionados, they are murderers in the making:

That which to the outside world must appear to be nothing more than an innocent and peaceful game to safeguard the health of the nation, must in fact be a preparation for war, and must also be appreciated in all its seriousness by the population at large. There is now a university for sport and a sports academic is at least on a par with any other academic - undoubtedly superior to them in the eyes of the Führer. The significance of this evaluation is corroborated and encouraged in the mid-1930s by the names given to cigarettes and cigarillos: people smoke 'Sportstudent' and 'Wehrsport (military sport)' and 'Sportbanner' and 'Sportnixe' (sporting belle). ${ }^{8}$

With the surrender of Nazi Germany, the reputation of academic athletics lay in ruins. In 1947, Carl Diem, organiser of the 1936 Berlin Olympics, surveyed the extent to which German university sports had compromised itself during the Third Reich. "A consequence of the destructive policies instituted during the Nazi era," Diem wrote despondently, "is 
that the $[P E]$ institutes are currently fighting for acceptance and that there are [presently] universities which reject such institutes, as if it were possible to exclude [physical education] from academic pedagogy". ${ }^{9}$

Those who had been forced into exile to escape the genocidal antisemitism of the Nazis came close to writing off sports altogether. Theodor W. Adorno identified "athletic events" as "models for totalitarian mass rallies." As "tolerated excesses," he wrote in a chilling juxtaposition, "they combine cruelty and aggression with an authoritarian moment, the disciplined observance of the rules - legality, as in the pogroms of Nazi Germany." $10 \mathrm{He}$ was unwilling to give up on the liberating possibilities of playful activity, but these were only too rare, precluded by ideological and economic constraints. For Adorno, real existing sport was shackled to a logic of production that not only weighed down its ludic potential but rendered that potential all but inoperative. Where others saw wholesome cavorting and the free movement of bodies, Adorno railed against a physical regimen that churned out pliable cogs for the capitalist machinery. "The rules of the game resemble those of the market, equal chances and fair play for all, but only as the struggle of all against all." Sport itself has degenerated into a "ritual in which the subjected celebrate their subjection." 11

Wehler, on the other hand, kept up a gruelling running routine well into his university days in post-war West Germany. Until 1955, he confessed, "I could not imagine life without two or three hours" of running a day. ${ }^{12}$ Even in his later years, he was able to rattle off his personal records over 400 and 800 meters. Close friends put down Wehler's astonishing productivity as an academic to the performance ethic he imbibed on the track. The rebellious students that confronted him in 1968 would have concurred, but for them it was not a flattering observation. Wehler's Leistungsterror (performance terror), they charged, was clearly a remnant of his indoctrination in the Hitler Youth. Ironically, it was Wehler himself who underlined the continuities between the obsession with performance under National Socialism and the economic boom of the post-war decades. The Wirtschaftswunder tapped into a deep-rooted potential that had matured thanks to the sporting craze of the Nazis. As far as his own biographical trajectory was concerned, however, Wehler added another twist to his passion for PE. When he successfully applied for a Fulbright scholarship - he was part of one of the first German cohorts to benefit from study-abroad in the US - what most impressed the selection committee was not so much his command of English, he surmised, as his intimate knowledge of every American sprinter who had run the 100 meters in under 10.2 seconds. ${ }^{13}$ His athletic Westbindung underpinned his intellectual reorientation towards the West.

\section{References}

1. Michael Krüger, Einführung in die Geschichte der Leibeserziehung und des Sports, vol. 2, Leibesübungen im 19. Jahrhundert - Turnen fürs Vaterland, Schorndorf: Karl Hoffmann, 1993, p. 36-50.

2. Christiane Eisenberg, "English Sports" und deutsche Bürger. Eine Gesellschaftsgeschichte 1800-1939 Paderborn: Ferdinand Schöningh, 1999. 
3. Michael Krüger, "Gymnastics and Sport at German Universities: The Example of the Teacher Training College in Tübingen from the Beginnings to Its Academic Acceptance", The International Journal of the History of Sport 32, no. 6, 2015, p. 770-788, here p. 778. https://doi.org/10.1080/09523367.2015.1020302.

4. Udo Merkel, "The Politics of Physical Culture and German Nationalism: Turnen versus English Sports and French Olympism, 1871-1914”, German Politics \& Society 21 , no. 2 , summer 2003, p. 69-96, here p. 81-2. https://doi.org/10.3167/104503003782353501.

5. Karl Planck, Fußlümmelei. Über Stauchballspiel und englische Krankheit, Stuttgart: Kohlhammer, 1898.

6. Susan Brownell, "Sport since 1750", in Cambridge World History, vol. 7, Production, Destruction and Connection 1750-Present, pt. 2, Shared Transformations?, edited by J. R. McNeill and Kenneth Pomeranz, Cambridge: CUP, 2015 p. 225-248, here p. 228-9, 236. https://doi.org/10.1017/CBO9781316182789.011.

7. Paul Sturm, Die seelischen und sittlichen Werte des Sports, insbesondere des Fußballsports, als Grundlage zur Befreiung aus der Knechtschaft, Stuttgart: Chr. Belser, 1924, quoted in Michael Krüger, "Gymnastics and Sport at German Universities", p. 780.

8. Victor Klemperer, The Language of the Third Reich, London: Bloomsbury Academic, 2013, p. 237.

9. Quoted in Michael Krüger, "Sports in the German University from about 1900 until the Early Years of the Federal Republic of Germany: The Example of Muenster and the "Westfaelische Wilhelms-University"', The International Journal of the History of Sport 29, no. 14, September 2012, p. 1981-1997, here p. 1991. https://doi.org/10.1080/09523367.2012.694072.

10. Theodor W. Adorno, Prisms, Cambridge: MIT Press, 1997, p. 79

11. Theodor W. Adorno, The Culture Industry, London: Routledge, 2005, p. 89-90. https://doi.org/10.4324/9780203996065.

12. Hans-Ulrich Wehler, Eine lebhafte Kampfsituation. Ein Gespräch mit Manfred Hettling und Cornelius Torp, München: C.H. Beck, 2006, p. 31.

13. Ibd, p. 63.

SUGGESTED CITATION: Scholz, Danilo: At the sports ground, with footnotes (I): Stretching for the Fatherland, in: KWI-BLOG, [https://blog.kulturwissenschaften.de/atthe-sports-ground-with-footnotes-i/], 15.11.2021

DOI: https://doi.org/10.37189/kwi-blog/20211115-0830 
DuEPublico

Duisburg-Essen Publications online

\section{De}

offen im Denken

$$
\mathbf{U b} \mid \begin{aligned}
& \text { universitäts } \\
& \text { bibliothek }
\end{aligned}
$$

This text is made available via DuEPublico, the institutional repository of the University of Duisburg-Essen. This version may eventually differ from another version distributed by a commercial publisher.

DOI: $\quad$ 10.37189/kwi-blog/20211115-0830

URN: urn:nbn:de:hbz:464-20211115-100320-2

All rights reserved. 